УДК 664.1.03

\title{
ADVANCED TECHNOLOGY OF USING ALUMINUM HYDROXIDE IN SUGAR PLANTS OF UKRAINE
}

\author{
V. Olishevskyy, E. Babko, N. Pushanko, A. Ukrainets, D. Babko \\ National University of Food Technologies
}

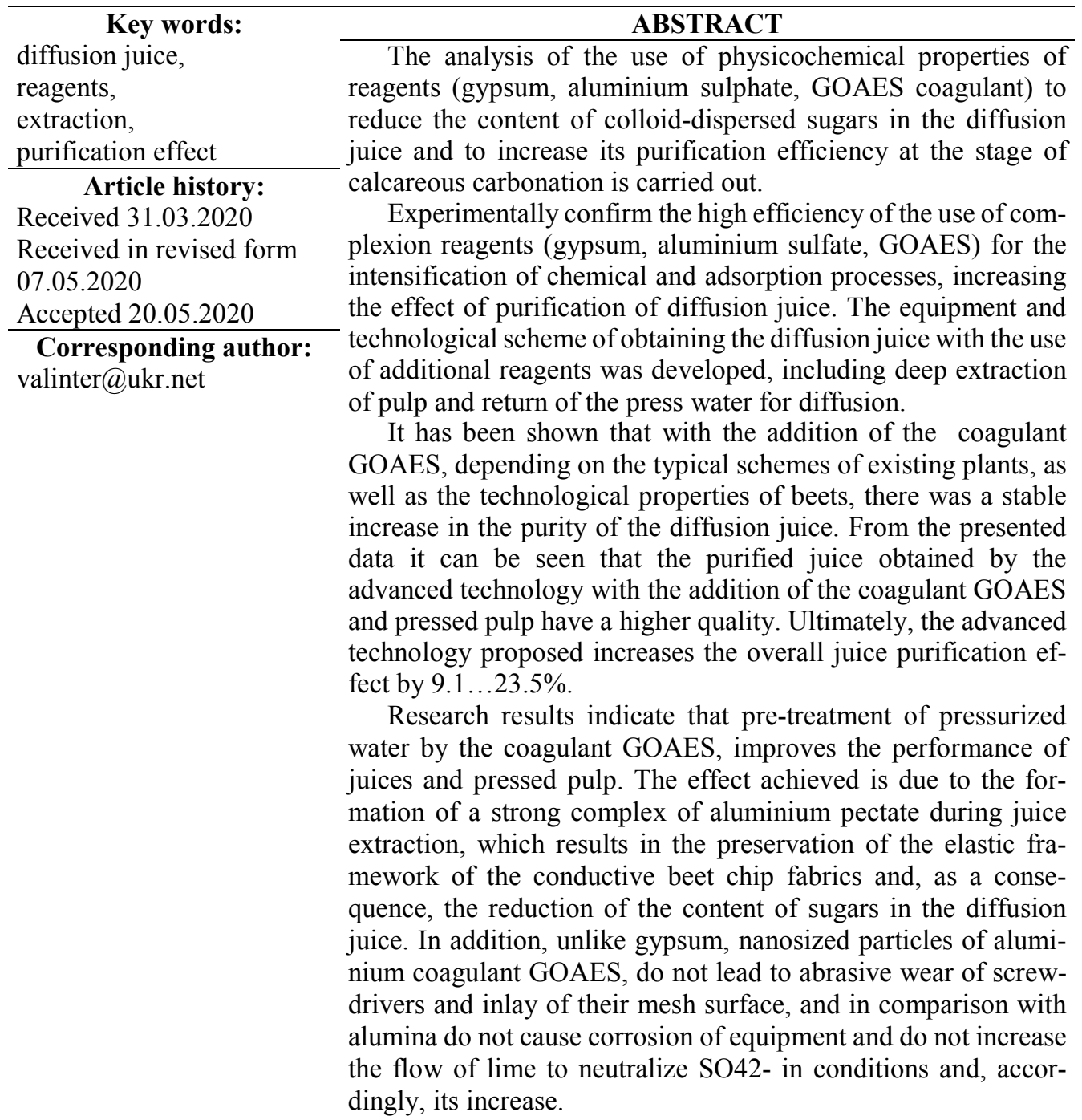

DOI: $10.24263 / 2225-2916-2020-27-12$

(c) В. В. Олішевський, Є. М. Бабко, Н. М. Пушанко, А. І. Українець, Д. Є. Бабко, 2020 


\title{
ПЕРЕДОВА ТЕХНОЛОГІЯ ВИКОРИСТАННЯ ГІДРООКСИДУ АЛЮМІНІЮ НА ЦУКРОВИХ ЗАВОДАХ УКРАЇНИ
}

\author{
В. В. Олішевський, к.т.н. \\ Є. М. Бабко, к.т.н. \\ Н. М. Пушанко, к.т.н. \\ А. І. Українець, д-р техн. наук \\ Д. Є. Бабко \\ Національний університет харчових технологій
}

У статті розглянуто практичне застосування хімічних реагентів (гіпсу, сульфату алюмінію, коагулянту ГОАЕС) в процесі екстрагування сахарози з бурякової стружки в умовах иукрових заводів ряду вітчизняних компаній. Показано, що використання додаткових реагентів дає змогу підвищити ефективність сокодобування та повноту осадження нецукрів на різних технологічних стадіях. Для впровадження в умовах иукрових заводів запропоновано спосіб екстрагування сахарози з дозуванням коагулянту ГОАЕС в кількості 0,002\% до м.б.

Ключові слова: дифузійний сік, реагенти, екстрагування, ефект очищення.

Постановка проблеми. Якість дифузійного соку залежить від вмісту в ньому нецукрів, що обумовлено багатьма факторами, важливими з яких є технологічні показники сировини й екстрагенту в процесі сокодобування (табл. 1) [1].

Якість дифузійного соку, що направляється на стадію кальцій-карбонатного очищення, суттєво залежить від умов проведення процесу екстрагування сахарози в дифузійному апараті [2; 3].

Таблиця 1. Класифікація дифузійних соків за К. Вуковим, [1]

\begin{tabular}{|l|c|c|c|}
\hline \multirow{2}{*}{ Вміст нецукрів } & \multicolumn{3}{|c|}{ Якість дифузійного соку } \\
\cline { 2 - 4 } & Добра & Середня & Погана \\
\hline Чистота, \% & $\geq 88,0$ & $85,5-88,0$ & $\leq 85,0$ \\
\hline Загальні нецукри, \% до м.б. & $\leq 2,0$ & $2,0-2,6$ & $\geq 2,6$ \\
\hline Зола, \% до м.б. & $\leq 0,5$ & $0,5-0,7$ & $\geq 0,7$ \\
\hline Редукуючі речовини, \% до м.б. & $\leq 0,15$ & $0,15-0,025$ & $\geq 0,25$ \\
\hline Альфа-амінний азот, \% до м.б. & $\leq 0,025$ & $0,025-0,04$ & $\geq 0,4$ \\
\hline Колоїди, \% до м.б. & $\leq 0,4$ & $0,4-0,8$ & $\geq 0,8$ \\
\hline Пектини, \% до м.б. & 0,1 & $0,1-0,2$ & $\geq 0,2$ \\
\hline
\end{tabular}

При цьому для одержання якісного дифузійного соку та підвищення виходу цукру за раціональної витрати вапна необхідно:

- досягати максимального очищення коренеплодів кондиційного цукрового буряку від легких і важких домішок та отримувати високоякісну стружку;

- застосувати в дифузійному процесі високоякісну живильну воду;

- використовувати додаткові хімічні реагенти для підвищення ефекту очищення дифузійного соку в дифузійному апараті (алюміній- та кальцієвмісні коагулянти);

- підтримувати високий ступінь віджимання свіжого жому та повернення всієї жомопресової води в дифузійну установку.

3 огляду на це проведено аналіз використання фізико-хімічних властивостей реагентів (гіпсу, сульфату алюмінію, коагулянту ГОАЕС) для зниження вмісту 
колоїдно-диспергованих нецукрів у дифузійному соку та підвищення ефективності його очищення на стадії вапнокарбонізації.

Мета дослідження: вдосконалення процесу екстрагування сахарози шляхом попередньої обробки жомопресової води гідроксидом алюмінію.

Матеріали і методи. Перший етап проведених досліджень [4-8] дав змогу теоретично обгрунтувати й експериментально підтвердити високу ефективність використання комплексоутворюючих реагентів (гіпсу, сульфату алюмінію, ГОАЕС) для видалення нецукрів і підвищення загального ефекту очищення дифузійного соку. На підставі цих досліджень розроблена апаратурно-технологічна схема одержання дифузійного соку з використанням додаткових реагентів, що включає глибоке віджимання жому та повернення жомопресової води на дифузію (рис. 1). Запропонований коагулянт ГОАЕС дозували мембранним насосом 4 з ємкості 3 в зону подачі жомопресової води в дифузійний апарат 2.

Дослідження проводилися у виробничі сезони 2016-2019 рр. на цукрових заводах ряду вітчизняних компаній «Юкрейніан Шугар Компані» (Миколаївська обл., 2016 р.); агропромхолдингу «Астарта-Київ: «Новоіванівський цукровий завод» (Харківська обл. 2017 р.), «Жданівський цукровий завод» (Вінницька обл., 2017 р.), «Наркевицький цукровий завод» (Хмельницька обл., 2019 р.).

Для досліджень використовували бурякову стружку, отриману при переробці буряків середньої та високої якості за типовими схемами цукрових заводів 3 використанням коагулянту ГОАЕС:

- схема заводів «Юкрейніан Шугар Компані» і «Жданівський цукровий завод» - екстрагування сахарози 3 додаванням коагулянту ГОАЕС в кількості 0,002\% до м.б.;

- схема заводів «Наркевицький цукровий завод» $\mathrm{i}$ «Новоіванівський цукровий завод» - екстрагування сахарози з додавання в типову схему гіпсу, сульфату алюмінію та коагулянту ГОАЕС в кількості, відповідно, 0,04\%, 0,02\% і 0,002\% до м.б.

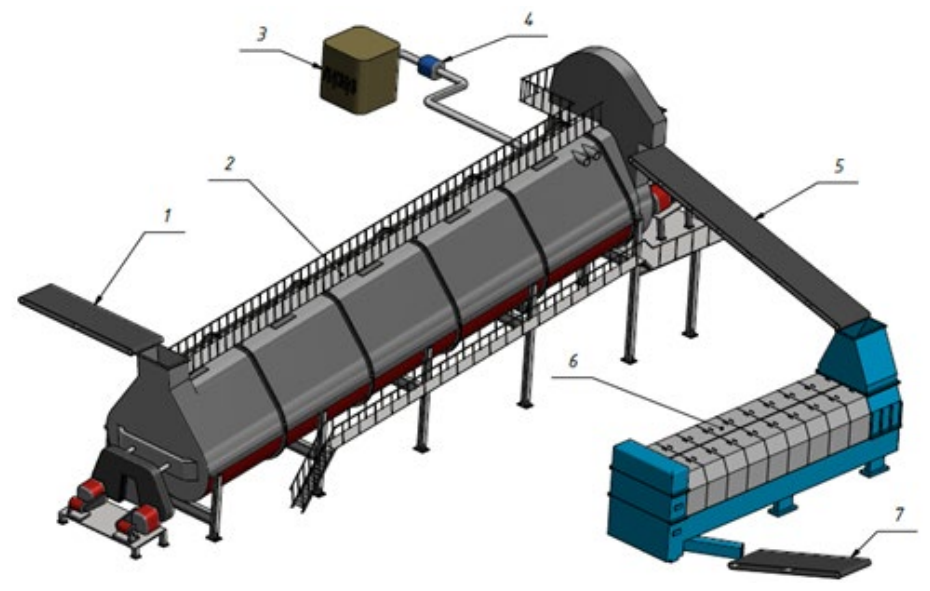

Рис. 1. Апаратурно-технологічна схема дифузійно-пресового способу екстрагування сахарози з використанням додаткових реагентів: $1,5,7$ - стрічкові конвеєри; 2 - дифузійна установка похилого типу; 3 - ємкість 3 коагулянтом ГОАЕС; 4 - насос-дозатор; 6 - прес для глибокого віджимання жому

При проведенні досліджень використовували водні розчини як традиційних реагентів - гіпсу $\left[\mathrm{CaSO}_{4} \cdot 2 \mathrm{H}_{2} \mathrm{O}\right]$ [9] та сульфату алюмінію $\left[\mathrm{Al}_{2}\left(\mathrm{SO}_{4}\right)_{3}\right]$ [10], так і 
реагенту нового покоління - нанорозмірного коагулянту ГОАЕС [11], що одержаний електроіскровим способом [12].

Технологічних показники напівпродуктів цукробурякового виробництва визначали за допомогою рекомендованих методик [13; 14].

Результати досліджень. Результати досліджень впливу додаткових реагентів на якісні показники напівпродуктів цукробурякового виробництва представлено в табл. 2.

Отримані результати свідчать про те, що всі додаткові реагенти покращують показники соків і пресованого жому, при цьому коагулянт ГОАЕС виявив кращі коагулюючі та комплексоутворюючі властивості. Досягнутий ефект пояснюється тим, що іони металів $\mathrm{Ca}^{2+}$ та $\mathrm{Al}^{3+}$ розчинів додаткових реагентів у процесі екстрагування по каналам пошкоджених під час різання поверхневих клітин бурякової стружки проникають в їхню будову, укріплюють клітинні стінки (пружно-міцнісний каркас) за рахунок утворення комплексів 3 пектинами i, як наслідок, знижують вмістув дифузійному соку нецукрів і сприяють підвищенню його чистоти.

Встановлено, що використання коагулянту ГОАЕС в кількості 0,002\% до м.б. порушує стійкість гетерогенної дисперсної системи, в результаті чого покращується агрегатування по всьому спектру крупності дисперсії, в т.ч. на ділянці частинок, що утворюють каламутність. За таких умов не погіршуються фільтрувальні властивості соків, а фільтрат та декантат переддефекованого соку мали меншу кольоровість і кращу прозорість (рис. 2). У результаті такої взаємодії в сатураційних соках утворюються міцели кальцієвого осаду більш щільної та упорядкованої структури $з$ прозорою рідкою фазою (рис. 3).

Таблиця 2. Вплив гідроксиду алюмінію, отриманого електроіскровим методом, на якісні показники напівпродуктів бурякоцукрового виробництва

\begin{tabular}{|c|c|c|c|c|c|c|c|c|c|c|c|c|}
\hline \multirow[b]{3}{*}{ Показники } & \multicolumn{12}{|c|}{ Схема екстрагування сахарози з бурякової стружки } \\
\hline & \multicolumn{3}{|c|}{\begin{tabular}{|c|} 
Юкрейніан \\
Шугар Компані, \\
2016 р.
\end{tabular}} & \multicolumn{3}{|c|}{\begin{tabular}{|c|} 
Жданівський \\
цукровий завод \\
2017 p.
\end{tabular}} & \multicolumn{3}{|c|}{\begin{tabular}{|c|} 
Новоіванівськнй \\
цукровий завод, \\
2017 р.
\end{tabular}} & \multicolumn{3}{|c|}{$\begin{array}{c}\text { Наркевнцький } \\
\text { цукровнй завод, } \\
2019 \text { р. }\end{array}$} \\
\hline & 㽞 & 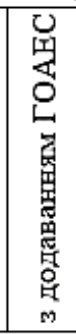 & $\begin{array}{l}\text { : } \\
\text { 品 } \\
\text { 慁 } \\
\text { 昌 } \\
\text { 웅 }\end{array}$ & 哭 & 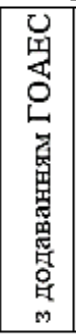 & 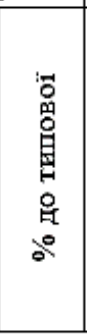 & 嘿 & 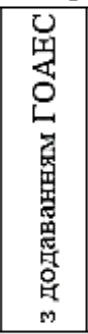 & 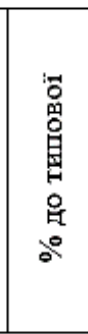 & 蔓 & 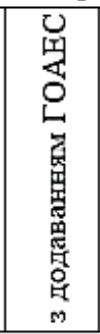 & 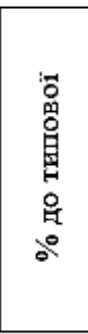 \\
\hline \multicolumn{13}{|c|}{ पистота, \%: } \\
\hline буряк & 86 & 86 & 0 & 88,9 & 88,9 & 0 & 88,2 & 88,2 & 0 & 90,37 & 90,37 & 0 \\
\hline дифузійного соку & 87,2 & 88,6 & $+1,6$ & 90,6 & 90,9 & $+0,4$ & 90,4 & 90,9 & $+0,6$ & 92,01 & 92,52 & $+0,6$ \\
\hline очнщеного соку & 89,8 & 91 & $+1,3$ & 92,5 & 92,9 & $+0,4$ & 92,3 & 92,8 & $+0,6$ & 93,5 & 94 & $+0,5$ \\
\hline \multicolumn{13}{|c|}{ Ефект очищення, \% } \\
\hline дифузійного соку & 16,2 & 21,0 & $+29,4$ & 16,6 & 19,8 & $+19,3$ & 20,7 & 25,5 & $+23,3$ & 18,5 & 24,1 & $+30,4$ \\
\hline очищеного соку & 19,5 & 23,1 & $+18,6$ & 23,3 & 23,7 & $+1,8$ & 21,2 & 22,7 & $+7,4$ & 19,9 & 21,1 & $+5,6$ \\
\hline сумарний & 35,7 & 44,1 & $+23,5$ & 39,9 & 43,5 & $+9,1$ & 41,8 & 48,2 & $+15,3$ & 38,5 & 45,2 & $+17,5$ \\
\hline $\begin{array}{l}\text { Вміст СР в } \\
\text { пресованому жомі, } \\
\%\end{array}$ & 25 & 27,4 & $+9,4$ & 16,2 & 17,3 & $+7,0$ & 18,4 & 19,26 & $+4,5$ & 23,44 & 24,23 & $+3,4$ \\
\hline
\end{tabular}




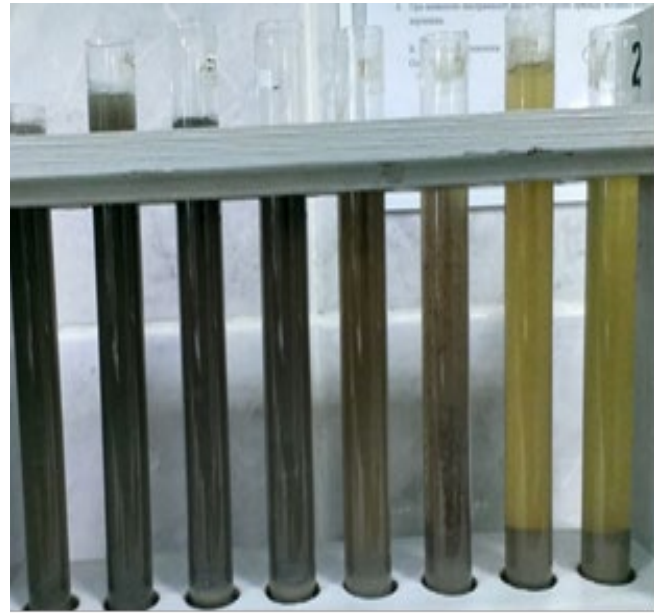

a

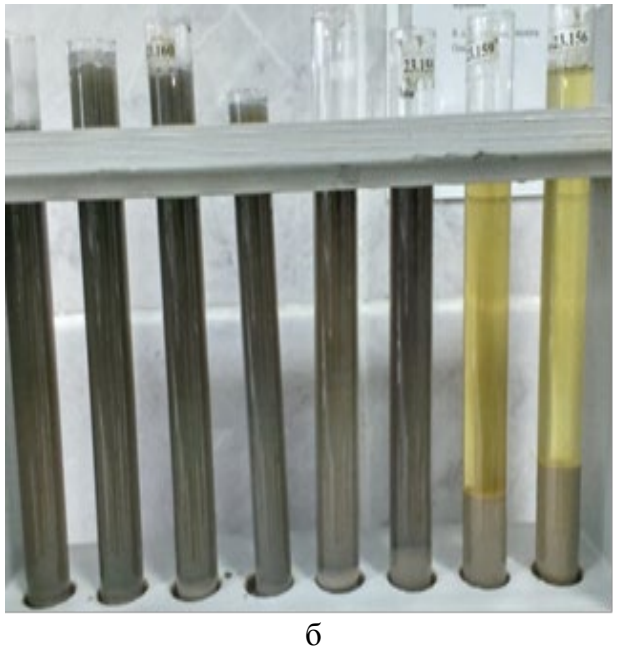

Рис. 2. Вплив коагулянту ГОАЕС на властивості соку попередньої прогресивної дефекації у виробничих умовах ТОВ «Юкрейніан Шугар Компані» (на фотографіях зліва на право зразки по зонах переддефекатора): а і б - відповідно без та $з$ додаванням ГОАЕС в процесі екстрагування

За весь період досліджень переробки буряка з додаванням коагулянту ГОАЕС, залежно від типових схем діючих заводів, а також технологічних властивостей буряків, спостерігалося стабільне підвищення чистоти дифузійного соку. 3 представлених даних видно, що отриманий за вдосконаленою технологією 3 додаванням коагулянту ГОАЕС очищений сік і пресований жом мають більш високу якість. Так, чистота дифузійного соку порівняно 3 типовою технологією на $0,4 \ldots 1,6 \%$ вище, а вміст сухих речовин у пресованому жомі вище на $3,4 \ldots 9,4 \%$ за рахунок поліпшення пружно-міцності стружки. У результаті вдосконалена запропонована технологія сприяє збільшенню загального ефекту очищення соку на $9,1 \ldots 23,5 \%$.

Результати досліджень свідчать про те, що попередня підготовка жомопресової води коагулянтом ГОАЕС покращує показники соків і пресованого жому. Досягнутий ефект пояснюється утворенням міцного комплексу пектату алюмінію під час сокодобування, внаслідок чого спостерігається збереження пружного каркаса провідних тканин бурякової стружки i, як наслідок, зменшенням вмісту нецукрів у дифузійному соці. До того ж, на відміну від гіпсу, нанорозмірні частинки алюмінію ГОАЕС не призводять до абразивного зносу шнеків жомопресів та інкрустації їхньої сітчастої поверхні, а якщо порівняти з сульфатом алюмінію - не викликають корозію устаткування і не сприяють збільшенню витрати вапна на нейтралізацію $\mathrm{SO}_{4}{ }^{2-}$ в умовах попередньої та основної дефекацій і, відповідно, його збільшення.

Висновки. В ході виробничих досліджень встановлено, що використання коагулянту ГОАЕС за суттєво меншій витраті (0,002\% до м.б.) дає змогу істотно стабільно підвищити ефективність вилучення сахарози.

Спосіб інтенсифікації дифузійно-пресового способу вилучення сахарози 3 бурякової стружки з використанням коагулянту ГОАЕС практично реалізовано на ТОВ «Юкрейніан Шугар Компані» ED\&F Man та агропромхолдингу «АстартаКиїв». 

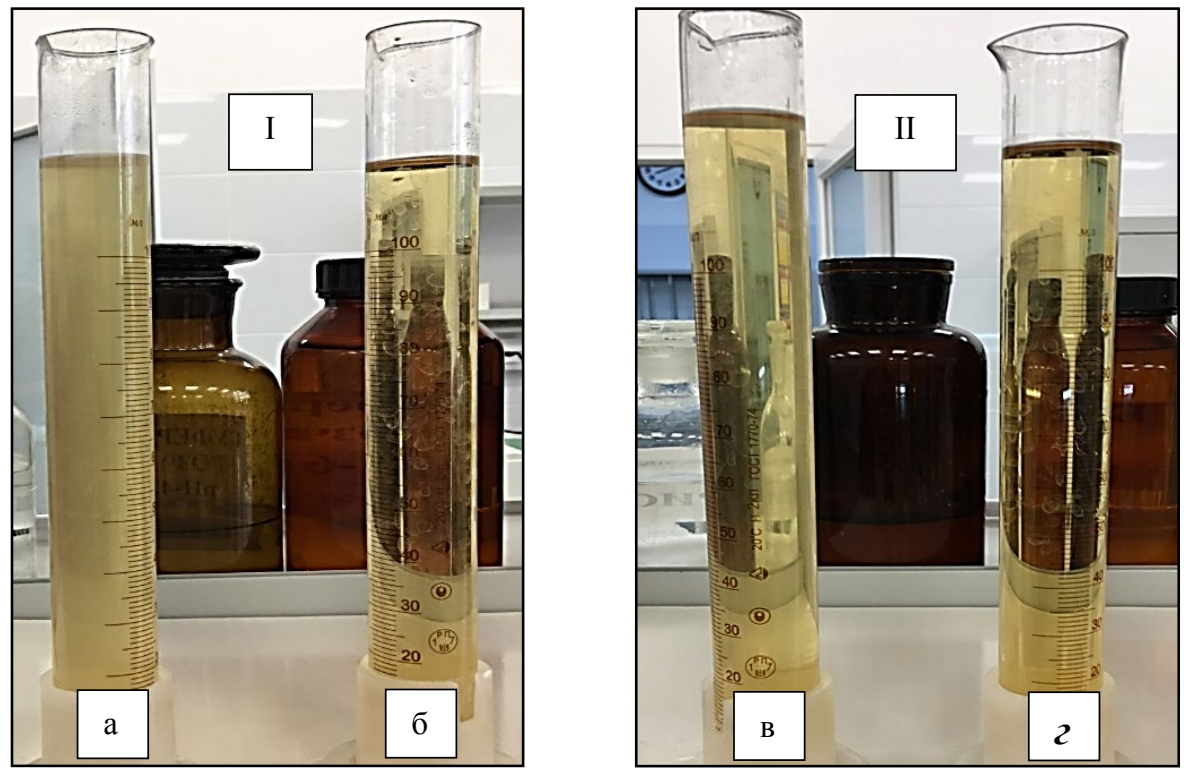

Рис. 3. Продукти сокоочисного відділення ТОВ «Наркевицький цукровий завод»:

I - типова схема: a - фільтрований сік I сатурації з каламутністю 495 од. ICUMSA; 6 - сульфітований сік з каламутністю 149 од. ICUMSA; II - типова схема 3 додавання

ГОАЕС: в — фільтрований сік І сатурації з каламутністю 167 од. ICUMSA; г - сульфітований сік $з$ каламутністю 69 од. ICUMSA

\section{ЛITЕРАТУРА}

1. Vukov K. Physik und chemie der Zuckerrübe als Grundlage der Verarbeitungsverfahren / K. Vukov. - Budapest: Akademiai Kiado, 1972. - 458 p.

2. Сапронов А. Р. Технология сахарного производства. 2-е изд., исправл. и доп. / А. Р. Сапронов. - Москва. Колосю 1999. - 495 с.

3. Asadi Mosen. Beet-sugar handbook /Includes bibliographical references and index / Asadi, Mosen. - Published by John Wiley \& Sons, Inc., Hoboken, New Jersey, 2007. — 868 p.

4. Nykytiuk Taras. Impact of nanosized aluminum hydroxide on the structural and mechanical properties of sugar beet tissue / Nykytiuk T., Olishevskiy V., Babko E., Prokopiuk O. // Ukrainian Food Journal. - 2018. — Vol. 7. iss. 3. - pp. 488 - 498.

5. Спосіб очищення дифузійного соку: пат. 104338 України: МПК С13В 20/00/ В. В. Олішевський, Л. М. Вєрченко, А. І. Маринін, С. В. Ткаченко, О. В. Ардинський, К. Г. Лопатько. № а 201204314; заявл. 06.04.2012; опубл. 27.01.2014, Бюл. №2.

6. Спосіб екстрагування сахарози з бурякової стружки: пат. 114866 України: МПК С13В 10/08, C13В 10/14. / В. В. Олішевський, А. І. Українець, Н. М. Пушанко, А. І. Маринін, С. М. Бабко, К. Г. Лопатько. № a 201606321; заявл. 10.06.2016; опубл. 10.08.2017, Бюл. № 15 .

7. Олішевський В. В., Українець А. І., Лопатько К. Г., Пушанко Н. М., Бабко Є. М., Вільченко А. М., Костюченко В. В., Маринін А. І., Никитюк Т. В., Лапшин С. О. Досвід використання нанокомпозиту алюмінію в умовах бурякоцукрового виробництва. Цукор України. 2016. № 11-12 (131-132). С. 11-16.

8. Олішевський В. В., Українець А. І., Бабко Є. М., Пушанко Н. М., Никитюк Т. В., Закордонець Д. І., Бартошак І. В. Вплив нанокомпозиту алюмінію на дифузійні властивості бурякової стружки. Цукор України. 2017. № 5(137). С. 17-23.

9. Гіпс будівельний Г-5 Н-IІ. ДСТУ Б.В. 2.7-82:2010.

10. Алюмінію сульфат технічний очищений. ДСТУ ГОСТ 30333:2009.

11. Коагулянт ГОАЕС. ТУ У 20.1-41063292-001:2017. 
12. Пристрій для отримання колоїду металу: пат. на корисну модель 113262 України: МПК В22F 9/08, В23Н 9/00. / В. В. Олішевський, Є. М. Бабко, О. П. Балтажи, С. О. Лапшин, К. Г. Лопатько. № u 201809540; заявл. 21.09.2018; опубл. 26.12.2018, Бюл. № 24 .

13. Инструкция по химико-технологическому контролю и учету сахарного производства. Киев. ВНИИСП. 1983. 476 с.

14. Правила ведення технологічного процесу виробництва цукру з цукрових буряків. Правила усталеної практики (ПУП) 15.83-37-106:2007. / Ярчук М. М., Калініченко М. Ф.,Чупахіна В. П. та ін. — Київ. 2007. — 420 с.

\title{
ПЕРЕДОВАЯ ТЕХНОЛОГИЯ ИСПОЛЬЗОВАНИЯ ГИДРОКСИДА АЛЮМИНИЯ НА САХАРНЫХ ЗАВОДАХ УКРАИНЫ
}

\author{
В. В. Олишевский, Е. Н. Бабко, Н. Н. Пушанко, А. И. Украинец, Д. Е. Бабко \\ Национальный университет пищевых технологий
}

В статье рассмотрены практическое применение химических реагентов (гипса, сульфата алюминия, коагулянта ГОАЭС) в процессе извлечения сахарозы из свекловичной стружки в условиях сахарных заводов ряда отечественных компаний. Показано, что использование дополнительных реагентов позволяет повысить эфрфективность сокоизвлечения и полноту осаждения несахаров на различных технологических стадиях. Для внедрения в условиях сахарных заводов предложен способ экстрагирования сахарозы с дозировкой коагулянта ГОАЭС в количестве $0,002 \%$ к м.С.

Ключевые слова: дифффузионный сок, реагенты, экстрагирования, эфрфект очистки. 